\title{
Law and order
}

Review of the problem of crime in recent decades

Descriptions of the various attempts which have been made to reduce crime since 1979

Analysis of different governments' attitudes to crime

Descriptions of legislation passed to deal with law and order issues

Analysis of theories concerning the causes of crime

Speculation as to how law and order issues may be dealt with in the future

Before examining the political issue of law and order as it has unfolded since 1979 , we need to define the scope of the subject. The following elements may be included under the general heading 'law and order'.

- The system of criminal law. How can it be kept up to date and used to combat law through conviction and deterrence.

- Crime and punishment. What are the most effective ways in which the sentencing of convicted criminals can be used to deter crime, to satisfy the victims of crime and to prevent re-offending.

- The law courts. How can they be organised to deal efficiently and effectively with crime.

- The prison and probation system. This needs to keep up with demand, ensure security from criminals for the community and to take measures to rehabilitate prisoners and try to avoid re-offending.

- Policing. How much should be spent on the service, how many officers should be employed, what equipment should be invested in and how should police forces be managed and deployed to combat crime.

- How to deal with potential breaches of public order. This concerns both the laws on public order and also how police are used. It also concerns the circumstances in which public meetings and demonstrations should be banned or curtailed.

- How to deal with the social and moral causes of crime. 
From time to time all these matters come to the attention of policy makers. Some may be stressed more than others at times, but they are all facets of the same problem.

Although the maintenance of law and order is one of the oldest and most basic functions of government, it has not been one of the main subjects of partisan conflict for most of the modern era in Britain. Crime and public disorder are the concern of all, but usually stand in the background of party politics. This has been for two main reasons:

1 There was a perception that politicians do not have it in their power to control crime levels. Crime was seen as a social problem which is inevitable and whose causes are complex.

2 Until the 1970s, crime levels, or at least known and reported levels of crime did not rise seriously. Nor was fear of crime seen as a major problem. It was rare enough for people to be affected by crime or public disorder so that other issues, such as the economic well-being of the country, foreign policy and welfare policy, were uppermost in their minds when making political judgements.

This led to a circumstance where there was a general consensus on law and order issues. The causes of growing crime rates were social and moral, more the concern of the churches, the schools and the courts than of politicians. The way in which crime could best be combated, all major parties agreed, was to remove the social causes of crime. Prosperity, educational opportunity, high employment and better housing were all seen as the best way of dealing with crime. Breakdowns in public order were, meanwhile, rare events. There had been some race rioting in the 1950s, youth violence in the 1960s, political demonstrations in the late 1960s and some violence during large-scale strikes, but most people were unaffected. The police, too, seemed capable of handling the outbreaks. No special legislation was seen as necessary.

During the 1970s this situation began to change. Crime levels were rising inexorably, especially crimes against property and cars, and violent and sexual offences. This also meant that the fear of crime was growing. Public disorders also grew with large industrial strikes becoming more violent and football hooliganism growing.

An increasingly alarmed public turned to the politicians for solutions. Under this pressure the political consensus on law and order collapsed. The Labour party remained committed to policies which were designed to deal with the social causes of crime. The Conservative party, however, moved steadily towards a harder-line approach. For them the laws needed to be reviewed, police and law courts to be given greater powers' and public disorders controlled. The Liberals (later Liberal Democrats) shared a social view of crime with the Labour party, but also emphasised the threat to human rights of the Conservatives' increasingly severe policies. 
The election campaign of 1979 marks a clear end to the consensus. The Labour party was still arguing that economic prosperity and reduced unemployment would solve many of the problems of crime. Restoration of communities, better housing and social services were also seen as basic answers. This was rejected by the Conservatives who actually blamed many of the policies of the Labour government of 1974-79 for the rising crime rate. Labour's 'soft' approach to trade unions led to public disorders. An extremely liberal approach to young offenders - largely replacing custodial sentencing with community work, probation supervision and the involvement of social services with young criminals - was criticised as failing to deal with delinquency. The electorate agreed. Conservative law and order policies were certainly one of the factors which brought them to power.

\section{THE CONSERVATIVES IN POWER, 1979-97}

The first seven years of the administration of Margaret Thatcher saw one of the greatest onslaughts on crime and disorder ever seen in Britain. The issue was attacked on all levels. The main developments were as follows:

- There was a steady increase in the size of the police force. Police pay was raised by 16 per cent to raise morale and boost recruitment. Between 1979 and 1984 expenditure on policing more than doubled. From 1979 to 1983 police numbers rose from 110,000 to 120,000 in the UK.

- To meet the demand for greater custodial sentences, eight new prisons and four youth detention centres were built between 1979-84.

- The Criminal Justice Act of 1982 gave magistrates much greater powers to imprison offenders and to lengthen sentences. More importantly a system of youth custody for very young offenders was introduced. This policy was known as the short sharp shock and was based on a belief that if a young criminal was given a short but strict period of custody it would nip their criminal tendency in the bud. The policy was highly controversial. Many sociologists were convinced it would not work and that the detention centres (sometimes known as 'boot camps') would only be breeding grounds were young offenders would learn crime from older inmates.

- The Police and Criminal Evidence Act (PACE) of 1984 marked a considerable increase in police powers. The ability to stop and search those suspected of committing or even contemplating crime was extended. It also became possible to question suspects for extended periods of time with the permission of a magistrate. The compulsory recording of interviews of suspects went some way to balance out the greater questioning powers, but the overall effect of PACE was to change the balance of power markedly in the direction of the police. 
- In 1986 the Public Order Act was passed. This was a response to the inner city disturbances which had occurred in London, Liverpool, Bristol and other cities, and to the conduct of the miners' strike of 1984 when there was extensive violence around the pits and severe challenges to police peace lines. The Act gave the police extensive powers to prevent marches and demonstrations if they believed that breaches of the peace might result. Rioting itself became a special crime and curbs were introduced on the activities of trade union pickets who may try to prevent non-union workers entering factories and mines.

- New training was introduced for the police, enabling them to become almost a paramilitary force when facing serious public disorder.

These measures, and the general climate of policy makers being hard-line on crime issues, proved to be popular. However, the figures suggest they were unsuccessful. Crime levels continued to grow inexorably (see tables 6.1, 6.2 and 6.3). This led to a re-examination of policies after 1987.

Table 6.1 Crimes reported in the British Crime Survey (millions)

\begin{tabular}{ccc}
\hline Year & Total crimes & Violent crimes \\
\hline 1981 & 11.0 & 2.2 \\
1983 & 11.9 & 2.1 \\
1987 & 13.3 & 2.3 \\
1991 & 15.1 & 2.7 \\
1993 & 18.6 & 3.6 \\
1995 & 19.2 & 4.1 \\
1997 & 16.4 & 3.4 \\
1999 & 14.7 & 3.2 \\
2000 & 12.9 & 2.6 \\
\hline
\end{tabular}

Source: British Crime Survey.

Table 6.2 Total drugs seizures, 1981-99

\begin{tabular}{rrrrrr}
\hline Year & Cannabis & Heroin & Ecstasy & Cocaine & Crack \\
\hline 1981 & 17,227 & 819 & $\mathrm{n} / \mathrm{a}$ & 503 & $\mathrm{n} / \mathrm{a}$ \\
1991 & 59,420 & 2,640 & 1,735 & 1,401 & 583 \\
1995 & 91,325 & 6,468 & 5,513 & 2,210 & 1,444 \\
1998 & 114,667 & 15,188 & 4,849 & 5,207 & 2,488 \\
1999 & 97,356 & 15,108 & 6,438 & 5,619 & 2,436 \\
\hline
\end{tabular}

Source: Home Office. 
Table 6.3 Offences per 10,000 people, by age range

\begin{tabular}{lcc}
\hline Age range & Male & Female \\
\hline $10-15$ & 221 & 85 \\
$16-24$ & 597 & 123 \\
$25-34$ & 250 & 57 \\
$35+$ & 47 & 11 \\
\hline
\end{tabular}

Source: Home Office.

\section{7-93: retreat from the hard line}

By 1987 it was apparent that law and order policies, especially those designed to contain the crime rate, were failing. Furthermore there was a complete reappraisal of the hard line approach by policy makers. Attention switched once again to the social causes of crime and to the belief that severe custodial sentences, especially for the young, were ineffective. At the same time a new initiative was developed. This was a community-based approach to crime reduction. The changes which occurred in the period can be summarised as follows:

- Local authorities were given greater responsibility for crime reduction. Improvements in the condition of communities, neighbourhood watch schemes and the idea of community policing were all to be undertaken at local government level. Community policing was thought to be particularly important. The policy was that local police forces should become integral parts of their communities, with close links between officers and local agencies, schools, youth groups, tenants organisations etc. By so doing it was hoped that the police would be

community policing

An idea that the police should see themselves as part of the community, not separate from it. Officers should get to know the community and so be able to protect people, gain their trust and obtain information about law breaking. seen, not as outsiders, but as part of the fabric of local society. It was also expected that local authorities would create schemes for young unemployed and offenders which would provide employment or other projects to divert them from crime.

- Tough sentencing policies were relaxed. The courts and probation service were encouraged to find alternatives to prison and detention centres. The main device was to be community service and probation orders which were to be more active in attempting to rehabilitate offenders. This policy was legislated in the Criminal Justice Act 1991. Judges and magistrates were required to justify prison sentences and only give them in the case of serious crimes.

- There was a steady rise in the number of police officers and probation officers employed. 
The course of policy and law and order was hampered considerably by a lack of consensus about how best to stem the alarming rise in crime statistics and by the fact that there was little continuity in policy. There were four different Home Secretaries in the period - Douglas Hurd (1985-89), David Waddington (1989-90), Kenneth Baker (1990-92) and Kenneth Clarke (1992-93) reflecting the relatively low profile of the issue in the government's political programme. To make matters worse, an economic recession struck the country in 1990. Rising unemployment, which resulted, led to a further leap forward in the crime statistics.

So, by 1993 Conservative policy on law and order appeared to be in disarray. Both the hard line and the community-based approaches seemed to have failed. The party, which normally led Labour comfortably on this issue, began to lose public confidence. It was time for a radical initiative. This was provided by the appointment of Michael Howard as Home Secretary in that year.

\section{The 27-point plan for law and order}

When Michael Howard took over as Home Secretary he signalled a complete reversal of Conservative law and order policy. Cynics have argued that this was a response to the unpopularity of the government as it struggled to overcome the effects of a major economic recession. A more objective explanation is that it was the result of continued rises in crime rates and clear public demands for a tougher stance. Youth crime represented a main concern and Howard went a long way to addressing this particular aspect of the problem.

At the Conservative party conference in the autumn of 1993 Howard declared that 'prison works', and criticised his predecessors' policies as being too soft on crime. As the title '27-point plan' suggests his policy was broad and comprehensive. Its main features were contained in the Criminal Justice and Public Order Act of 1994 and were as follows:

- To tackle juvenile crime Michael Howard announced the introduction of secure detention centres for 12- to 14-year olds. This group had previously been placed into local authority hands for education and rehabilitation. At the same time magistrates were given powers to give longer custodial sentences to 15- to 16-year olds.

- It had long been a complaint of the police and the courts that the law was weighted in favour of accused persons. The main culprit was the ancient 'right to silence' which allowed suspects and defendants to remain silent without this being allowed to be used against them in court. So, a suspect who refused to answer police questions and/or who refused to testify in court was protected from suspicion on the grounds of silence. The absolute right was, therefore, removed. This marked a change in the criminal law which overturned a centuries-old principle allowing a person to refuse to 
answer questions which may incriminate him or her (this is the famous fifth amendment of the United States Constitution). Accused persons who choose to remain silent may have the fact referred to in court and magistrates or juries may take the silence into account when judging guilt.

- The police were given increased powers to limit demonstrations and public meetings. Open-air 'rave' parties were effectively banned, squatting was made a criminal offence, as was trespass on private land. These measures extended police powers greatly and, most controversially, particularly affected young people. They were designed to control the activities of groups of homeless or travelling people who were often seen as a public nuisance and seedbeds of crime.

- The rules on bail were tightened so that it became very difficult for those who commit violent crime or are persistent offenders to be given bail. This resulted in a sudden increase in the numbers of people held on remand in custody. The police had asked for this measure on the grounds that accused people on bail very often committed repeat offences.

The Criminal Justice and Public Order Act of 1994 was an extremely controversial piece of legislation which received widespread condemnation as an infringement on human rights and a step backwards in the treatment of juvenile crime. But its author, Michael Howard, was unrepentant and continued his crusade to prove that a harsher regime would eventually make an impact on crime figures.

Also in 1994 the Police and Magistrates' Courts Act was passed. This made changes in the management of the police. It involved much greater central control over police policy, in the hands of the Home Office. By reducing the influence of local authorities, Howard hoped that policing could become more effective. It effectively marked the end of the experiment with community policing. More significantly, the Act introduced performance targets for police authorities. It was hoped that a system of targets for clearing up crime would concentrate minds and result in better detection rates.

Finally the Crime Sentences Act of 1996 allowed for much higher minimum sentences, especially for repeat offenders, and those convicted of violent, drugs or sexual offences. For those already in prison the parole and early release system was severely reduced. More prisoners would now serve their full term. For younger offenders a system of curfews was allowed, permitting the police to impose movement restrictions of juvenile offenders.

The result of these measures was to increase the prison population from 47,000 in 1993 to 60,000 in 1997. On the positive side there were signs in 1997 that the rise in crime was slowing down and, in the case of some offences, was falling. Clear-up rates by the police also began to improve. 
The post-1997 policies of the Conservative administration also have to be seen in the context of a marked shift in the party's moral outlook. Prime Minister John Major had announced in the early 1990s a new moral initiative which he titled 'back to basics'. The policy was designed to restore a stronger sense of moral responsibility and to try to re-establish Christian and family values. Criminals were seen as responsible for their own actions and the liberal notion that the causes of crime are predominantly social, was rejected. The term 'New Right', which has been applied to the more authoritarian policies of the Conservatives in the 1980s and 1990s, could be applied most directly to the law and order policies of Michael Howard.

They can also be viewed as a direct attack on many civil liberties which had been closely guarded in the United Kingdom for many years, even centuries. When added to the more draconian measures of the 1980s, they also mark a significant increase in the powers of the police. Citizens can be prevented from demonstrating in public or from forming any large gatherings which caused the police to believe there might be breaches of the peace. Individuals can routinely be stopped and searched by police officers. Accused persons may be held in custody for up to three days (longer still if suspected of terrorism). If they choose to remain silent, it may be held against them in court. Young people are much more likely to be given custodial sentences and these sentences may be for substantial periods. It is more difficult to obtain bail and prisoners are often denied the opportunity for parole or early release if they show signs of rehabilitation. Finally, judges and magistrates have had much of their power over sentencing reduced. There are now statutory minimum sentences for a range of crimes. This marks a significant shift in responsibility for the treatment of convicted criminals from the judiciary to politicians.

The Labour party, whose law and order policies were largely formulated by Tony Blair, the shadow Home Secretary until 1994, and his successor Jack Straw, opposed many of these policies. They, along with the resurgent Liberal Democrats, criticised the attack on civil liberties and the neglect of the social causes of crime. But it was clear that a new Labour government would not abandon all the Howard policies. Indeed, aware that a tough stance on law and order was a vote winner, Blair promised to be as hard on criminals as the Conservatives had been. But the traditional Labour view that crime has mainly social causes, meant that Blair had to promise that these too would receive the party's attention.

Tony Blair's 1993 assertion that Labour would be 'tough on crime and tough on the causes of crime' reflected this dual approach. However, when the party unveiled its programme of action on crime in 1995, the measures looked to be as severe as Michael Howard's had been. As the 1997 election loomed, the two main parties seemed to be engaged in a contest to see which of them could be 
seen as harsher line on crime in the eyes of the electorate. Thus, in many ways, a new consensus on law and order had emerged even though the two main parties claimed to have distinctive policies in the 1997 campaign.

\section{TOUGH ON CRIME AND TOUGH ON THE CAUSES OF CRIME - NEW LABOUR'S RESPONSE}

As Labour's policies on law and order began to unfold in its early years of office, it became clear that there was a great deal of continuity between the Conservative policies of Michael Howard and those of Jack Straw. There were, however, different emphases and it is certainly true that the Labour programme was more extensive than its predecessors.

Much of the programme was inspired by the experience of Mayor Giuliani of New York and his conspicuous success in reducing crime. His policy was commonly described as 'zero tolerance', though it was much more than a drive against minor offences. The New York scheme suggested that 'low-level' crimes such as begging, minor drug dealing, drunkenness and general disorderly behaviour, if left unchecked, would soon grow into more general criminal behaviour. They

zero tolerance

An idea developed in New York. The police refuse to tolerate small crimes such as begging, graffiti and vagrancy. By doing so it is believed to discourage people from drifting into more serious crime. It also helps to reduce the fear of crime. In New York it has been dramatically successful.

exacerbated the fear of crime and socialised vulnerable younger people into a life of more serious offending. The effects on the crime statistics, especially violent crime, in New York were dramatic, with crimes falling by 15 per cent in 1995 alone. Murders fell from just over 2,200 to 990 between 1990 and 1996.

Jack Straw, who became Home Secretary in 1997, set about introducing a broad-based version of the New York experience. Youth offending was to be a priority as research indicated that most offences were committed by boys and men aged 15-25. The fact that government in Britain is able to make more social interventions than in the United States meant that a programme of attacks on the basic social causes of crime could be undertaken in a way which was less feasible in New York or America in general.

If we are to describe and assess policies since 1997, a summary of the policies is best divided into two sections, as suggested by Tony Blair's 1993 declaration, 'tough on crime and tough on the causes of crime'. 


\section{TOUGH ON CRIME}

The Labour programme appears to be the most extensive set of proposals to appear in modern times. Of course, some of the plan is little more than a set of objectives, targets and pledges. But there is also a good deal of legislation and concrete action.

\section{YOUTH CRIME}

In 1999 a major experiment was introduced. Anti-Social Behaviour Orders could be made against youths who were suspected of causing widespread crime and disorder within a particular community. The youths were ordered to cease their activities and, if they failed to do so, would be liable to prosecution for ignoring the order. This represented a completely new kind of offence, based on generalised behaviour rather than specific crimes.

The central piece of legislation was the Crime and Disorder Act of 2000. This was aimed very much at young, repeat offenders who are responsible for the majority of crime. A Youth Justice Board was set up in order to co-ordinate the government's efforts and to advise on new legislation. However, immediate action was taken to speed up the legal process of bringing offenders to trial. The system of giving young offenders repeated warnings was ended. A 'final warning' system was devised after which young criminals were to receive a full-scale trial and sentence. Curfews were introduced for child offenders and restrictions placed on offenders, preventing them from entering certain districts where they were known trouble-makers.

The youth crime policies were further beefed up in the Criminal Justice and Police Act of 2001. The scope of curfews was extended and more youth detention centres were announced. The main thrust of this Act, however, was an attack on what Jack Straw described as Britain's 'yob culture'. The main innovation was a system of fixed 'on-the-spot' fines which could be levied by police against 'disorderly behaviour'. Eight relevant offences were identified including such actions as public drunkenness, threatening behaviour and general violence. The purpose of this development was twofold - to provide summary justice and to allow the police to deal with general street disorders more effectively.

\section{General crime}

Although there was little evidence that serious crime among the older age groups was on the increase, there were also measures which were designed to 
deal with criminals of all ages. Minimum sentences were increased for a range of crimes of violence as well as sexual and drugs-related offences. Mandatory drugs testing for all suspects was introduced in the Crime and Public Protection Act of 2001.

The Act also forced sex offenders to submit themselves to police orders on their movements after release from prison. A sex offenders register had already been set up, but the new regulations gave greater discretion to the police in informing communities of the presence of such individuals. In extreme cases sex offenders could be forced to re-locate. The laws preventing them working with children were also toughened.

For some prisoners 'tagging' was sanctioned, an electronic system for tracing the movement of offenders on early-release schemes. Such prisoners were also subjected to stricter probation conditions, while those given community service orders were subjected to greater controls over their work.

But adult crime was no longer seen as a key problem and the Labour government was less active in this area than the Conservatives had been. Instead, it was intended that more effective policing, higher detection rates and better social conditions would automatically reduce the overall levels of crime.

\section{Football hooliganism}

The main drive against this widespread range of offences was spurred by the behaviour of England football supporters in the 1998 World Cup and the European Championships of 2000. The two main devices introduced were International and Domestic Banning Orders.

The orders were applied not only to known, convicted offenders, but also to those who were merely suspected of being likely to commit crimes. The subjects of the orders could be banned from travelling to specific football matches, be required to report to police stations while matches were taking place and, most controversially, could be forced to surrender their passports when matches abroad were taking place.

The orders were largely at the discretion of the police and did not require sanctions by the courts. Thus some level of guilt was being presumed and the basic right of freedom of movement could be denied to individuals who had broken no laws, or at least had never been convicted of doing so.

\section{Policing}

Labour's attitude to policing was three-pronged. These concerned numbers, equipment and improving standards. Labour inherited a service which was 
suffering declining strength, low morale and a constant barrage of media criticism. The seemingly unstoppable rise in the levels of crime had sapped their confidence and, just as the crime statistics began to fall in the early 1990s, cuts in public expenditure began to bite.

While the new government wished to see an increase in police numbers after a decline during the 1990s, it was constrained by financial limits. Having committed itself to Conservative spending plans, the Home Office was forced to endure further reductions in police strength. It was not until 2000 that Gordon Brown was able to announce significant increases in spending. A plan to increase the service by 9,000 officers over three years was announced. By 2001 police numbers at last began to rise slowly. However, the increase was slow, being hampered by relatively low levels of pay and, in London especially, a reluctance among young recruits to locate in London or other expensive areas.

The second initiative promised to be more effective. The Home Office began to approve larger and larger numbers of closed circuit TV (CCTV) schemes, especially in inner cities and other crime 'hot spots'. The extensive use of speed cameras released officers from traffic duty and, as we have seen above, the force was given more powers to prevent public disorder I town centres. Disorderly behaviour in clubs or pubs could result in speedy closure on police recommendation and fixed penalties could be levied for offences of public disorder. In 2001 further measures were proposed to give the police a greater ability to secure convictions. The measures were promised a rough ride through parliament and widespread opposition among civil rights group, but David Blunkett, who took over as Home Secretary in 2001, seemed determined to push them through.

The right to trial by jury was to be removed for many 'medium level' offences under the Mode of Trial Bill. Apart from reducing the expense of the criminal justice system, it was also believed that juries were less likely to convict than magistrates. At the same time there were proposals to introduce 'double jeopardy', which would enable to courts to try a person more than once for the same offence provided new evidence was found. Like trial by jury, the double jeopardy rule was an ancient right, but was nevertheless to be dispensed with. A proposal which was to have similar effects was to allow courts to be told an accused person's past record before the verdict. Finally Blunkett decided that he would allow police forces to retain DNA records, not just on convicted criminals, bit also on anyone who had been a crime suspect, whether or not convicted. The overall effect of these proposals was, it was hoped, to tilt the balance of power decisively towards the police and away from accused persons. The Conservative Michael Howard's 1995 plea to 'take the handcuffs off the police' was being answered by a Labour administration! 
The police were to pay a price for their increased powers. The Crime and Public Protection Act established the power of the Home Office to set performance targets for police authorities. League tables of performance based on crime reduction and conviction rates were to be published. Forces were also required to contribute to Local Crime and Disorder Reduction Task Forces, encompassing the probation and local authority social services as well as the police. In other words, the police were to improve their performance both in reducing crime and in tackling some of the basic causes of crime and disorder (see box).

\section{Law and order legislation and increases in police powers}

- 1984 Police and Criminal Evidence Act. Increased police powers of stop and search. Extended allowed period of questioning without charge to 72 hours.

- 1986 Public Order Act. Increased the power of the police to prevent demonstrations which might lead to criminal activity.

- 1991 Criminal Justice Act. The courts were forced to justify custodial sentences, making it more difficult to imprison minor offenders.

- 1994 Criminal Justice Act. Took away people's right to remain silent and not have their silence held against them. Created a new offence of criminal trespass. Increased police powers to prevent demonstrations and rave parties. Violent criminals were not allowed bail while awaiting trial.

- 1996 Crime and Disorder Act. Forced courts to give longer sentences for serious offences.

- 2000 Crime and Disorder Act. Required the police to bring more young offenders to trial. Introduced a new offence of racially aggravated crime.

- 2001 Criminal Justice and Police Act. Introduced curfews for young offenders and instant justice for public disorder offences.

- 2001 Crime and Public Protection Act. Allowed police to keep a register of sex offenders and to restrict their movements after release from prison.

- 2002 Terrorism Act. Gave wide police powers to detect international terrorists, including inspecting bank accounts, mobile phone records and to search premises.

\section{THE CAUSES OF CRIME}

\section{Principles}

The Labour government subscribed to the view of Liberals and many sociologists that much crime has its roots in the very young. The seeds of criminal behaviour, they believed, were sown very young. They also accepted that the causes of crime were multi-faceted. Attempts to attack these causes, therefore, would also have to be pluralist. Strengthening the powers of the police and the courts could do so much, but it was not enough. 
Three basic New Labour principles were applied to the crime problem. The first concerned social exclusion. This phenomenon was identified as the tendency for some deprived portions of the population to become excluded from the normal benefits of the welfare state and so become alienated and disaffected. The sources of social exclusion included poor parenting, bad housing or homelessness, family unemployment, low educational attainment and truanting, drug misuse, general lack of opportunity, teenage pregnancy and chronic poor health. Clearly, many of those suffering from such exclusion are likely to turn to criminal activity.

social exclusion

A New Labour expression. It refers to those people, often young, who are excluded from mainstream society because of a variety of problems including low educational standards, unemployment, drug use, homelessness, petty crime, bad housing.

The second idea is joined-up government. Here, it is seen that, if social problems have many and varied causes, the solutions must also be pluralist. In practice this implies that a number of agencies, rather than just one, should be involved in solving the problems, Crime, especially among the young, should therefore not just involve the police and the courts. Social services departments, probation offices, schools, education welfare departments, community groups and youth organisations were also to be involved.

Finally, we should refer to the communitarian and active citizenship philosophies which are an important element of the New Labour programme. These approaches to all social policies are designed to promote the belief that individuals should feel responsible for what occurs within their own communities. 'Communitarianism' as a principle stresses that communities are largely responsible for their own welfare. While this includes such features as the physical environment, education, care of the elderly or needy and cultural life, the central element concerns law and order issues. Thus the existing neighbourhood watch schemes have received additional funding and publicity, while

active citizenship

Another New Labour idea. This suggests that people should take responsibility for their own communities. This includes helping to control criminal behaviour. residents are encouraged to report possible law-breaking (especially drugs offences) to the police and to become actively involved in preventing juveniles becoming involved in crime. Active citizenship, too, implies that we are not only responsible for ourselves and our families, but also have a social duty to involve ourselves in social action to make our communities better and safer to live in.

\section{MEASURES}

The most dramatic of the measures has been the Surestart programme with a budget of $£ 540$ million for three years. This identifies children, mostly below 
the age of 4, who are at 'multiple risk'. The agencies, working together as described above, are to intervene to try to prevent later trouble. Parents of such children are encouraged to take up parenting classes. Special nursery education is provided to try to ensure that children can integrate successfully into mainstream education. Children with special needs are to be subject to remedial action by all the agencies described above. As a corollary to this, negligent parents may be subject to criminal prosecution, especially for failing to ensure the children attend school.

On a broader front than Surestart, the New Deal for Communities was granted $£ 800$ million to be spent regenerating some of the most deprived communities in Britain, in which crime has been prone to ferment. Schemes for improved environments, housing, schools and remedial education schemes for habitual truants were introduced in selected districts.

Truancy, indeed, has been identified as a key factor in youth crime. Schools have been given targets for the reduction in truancy and league tables, similar to those for examination results, are being published. As we have seen above, parents are liable for prosecution if their children miss too much school. At the same time persistent offenders may be provided with special schooling designed to make education more relevant.

These and other schemes are supervised by Youth Offending Teams, staffed by multiple local agencies. These teams are charged not only with the task of improving the detection of criminals, but also with reversing criminal behaviour among individuals. This latter objectives involves a more active approach to punishment. Ways are to be found to force offenders to face up to their crimes and their victims. Thus, community service orders, special education and counselling may be used as well as custodial sentences.

\section{SOME THEMES}

\section{Civil liberties}

There is no doubt that, since 1979, all governments have been engaged in a consistent drive to halt the seemingly inexorable rise in crime and, hopefully, to start bringing the figures down. It is also clear that this drive has meant that a number of civil liberties, some of them very ancient, have either disappeared or come under serious threat. Indeed, in an interview with the author in the 1988, the then Home Secretary, Douglas Hurd, admitted that a major part of his role as a minister was to balance the community's desire for security from criminals and public disorder with individuals' right to civil liberty. He also 
accepted that this role was almost impossible, though it had to be undertaken. A review of these threats includes the following features:

- The position of those accused of crimes has been significantly altered. Above all the right to remain silent without this incriminating them has been removed by the Criminal Justice and Public Order Act of 1994. The police may question suspects for longer, in the case of suspected terrorists for seven days. DNA and fingerprint samples are routinely taken and are now retained, whether or not the suspect is convicted. Rape victims cannot be forced to confront their accused attackers directly in court and children are heavily protected in sensitive cases, being able to give evidence by video.

- On our streets, the police have also gained considerable powers. There is now an almost unrestricted right for the police to stop and search suspects. Summary justice may be meted out to those who are committing public order offences, with fixed-rate fines applying. Young offenders may have orders placed against them, preventing them from entering specific districts where they have committed crimes in the past. Many city streets are now scanned by closed circuit TV (CCTV) systems and many more such schemes were announced in August 2001.

- It is now more difficult to hold public demonstrations as the police have increased powers to prevent such events if they believe breaches of the peace may result. The right to hold open air parties and to gather on common land has also been curtailed.

- Motorists are regularly photographed or video'd if they are speeding and may be fined on the basis of this evidence alone. There are now proposals to extend video and photographic evidence to illegal parking. These measures are seen by civil rights groups as important infringements on the right to privacy.

- Severe restrictions may now be applied to individuals who are merely suspected of habitual criminal behaviour. Both convicted and suspected football hooligans may be prevented from travelling both at home and abroad and may have their passports confiscated. Known youth offenders may be excluded from certain districts even after they have been punished for their crimes.

- Convicted prisoners are now more likely to have to serve their full terms and have had their right to parole and early release curtailed. Released prisoners may be tagged or curfewed to restrict their movements. Children up to the age of 15 may also now have to observe a curfew, again in addition to any other punishment.

These, and many other less severe measures represent both a large extension in police powers and a loss of personal liberty. If, on the other hand, we test these developments against public opinion, there is little doubt that they have 
received the backing of the majority of the public as well as the law enforcement community.

\section{Are measures working?}

One of the problems of making an assessment of the Labour government's two-pronged attack on both crime and its causes is that it is difficult to establish how far success has been achieved.

The significant reductions in crime levels which began in the mid-1990s coincided with Michael Howard's tougher approach. It is therefore tempting to suggest that the approach works. On the other hand, the same period saw the onset of rising prosperity and falling unemployment, both of which might have a similar result. To further muddy the waters of this debate, police numbers were falling at this time while police powers were being extended.

Under Labour administrations the same dilemma exists. Most crime statistics continued to fall after 1997, but whether this was due to the even stricter policies of Jack Straw or whether more sympathetic social policies are having an effect may never be known, certainly not in the short run. If we are to assess whether New Labour has indeed been 'tough on crime and tough on the causes of crime' we may take a straightforward approach. In terms of the depth and variety of measures adopted, Labour's programme certainly looks more extensive then anything seen before. On the other hand we must also point once again to the better economic health of the country. This alone could be solely responsible for the lower crime statistics. It must also be noted that crimes of violence, which contribute so greatly to the public fear of crime, have continued to rise.

It is clear that both the main parties place a huge significance upon the law and order issue. It is also true that Labour has stressed the social aspects of the problem more than the Conservatives, but they have extended police powers as much as their predecessors. Labour places great store by police numbers and closer monitoring of police performance as a means of bearing down more forcibly on crime and disorder. Thus, Labour policies have certainly represented toughness on known criminals and an attempt to reduce the numbers of new ones by attacking the causes of crime. The extent to which tough talk is converted into success remains unclear.

\section{Terrorism}

During 2001 the attention of the Home Office was drawn to the problem of terrorism. Two pieces of legislation emerged. The first was the Terrorism Act of February 2001. This had two main effects. Firstly, it broadened the 
definition of a 'terrorist'. It could now include anyone, who in the opinion of the law enforcement authorities was planning any damage to the state. Civil Rights campaigners suggested it could be used against anyone who was planning any form of demonstration which might lead to damage to property. In other words, all pressure groups planning direct action might be under suspicion. Secondly, it allowed the police to hold for questioning a terrorist suspect for up to seven days with the permission of a minister. In other words, the government could create its own definition of a terrorist.

After the 11 September attack on the USA, stiffer measures were proposed.

\section{Future proposals}

\section{Terrorism}

The terrorist attacks on the USA in September 2001 and the anti-terrorist movement which followed them has given rise to a number of new possibilities. The most important suggestion has been the introduction of identity cards. On a broader front, there have been calls to increase police powers of property search or seizure, surveillance, internment of suspects and deportation. It seems likely too that police will be given even greater freedom to question terrorist suspects before bringing them to trial.

\section{Double jeopardy}

The Stephen Lawrence murder trial, when the police case collapsed for technical reasons gave rise to proposals to allow suspects to be tried twice for the same crime. In the Lawrence case further evidence emerged after the case had been heard, but could not be used because of the ancient double jeopardy rule. The police and Crown prosecution Service believe that more criminals would be brought to justice if the rule were to be removed.

\section{Trial by jury}

It is Labour government policy to reduce, though certainly not abolish, the right to be tried by a jury in medium-level offences (minor offences are already tried by magistrates only). This will, it is believed, speed up the process of law, reduce expense and ensure the conviction of more guilty offenders. It has been successfully fought off by civil rights campaigners, especially in the House of Lords, but government seems determined to change the law.

\section{Previous offences in trials}

Until now, an accused person's previous offences are not revealed in the course of a criminal case until the jury have delivered a verdict. The Home Office, 
with strong police backing, is considering changing this rule, again in order to secure more convictions.

\section{Sentencing}

The Labour administration would like to extend Michael Howard's programme of introducing longer mandatory sentences for serious offences. This would further erode the judiciary's control over punishment, placing it instead in the hands of political ministers. Though the Labour party stresses the causes of crime, they also accept in part Howard assertion that, in many cases, 'prison works'.

Whichever, if any, of these measures are introduced it seems likely that the process of extending police powers, reducing the rights of accused individuals and coming down harder on serious offenders will continue for the foreseeable future. It is also inevitable that civil rights campaigners will continue to resist such policies.

\section{SAMPLE QUESTIONS}

1 'Tough on crime, tough on the causes of crime.' What did Tony Blair mean by this 1994 assertion? In what ways have his governments since 1997 attempted to meet this commitment?

2 What special measures have been taken to combat youth crime since 1979 ?

3 How have police powers increased since 1979?

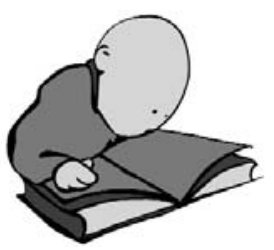

4 To what extent have the increases in police power since 1979 eroded human rights?

5 Describe and analyse the different approaches to crime adopted by Labour and Conservative governments. 